\title{
Inequality of Household Expenditure on Senior Students' Accessibility to Higher Education in Vietnam
}

\author{
Ha Van Hoang \\ Department of Social Work, Faculty of Psychology and Education, The University of Danang - University of Science and Education, \\ Danang, Vietnam
}

Received October 23, 2020; Revised November 27, 2020; Accepted December 20, 2020

\begin{abstract}
Cite This Paper in the following Citation Styles
(a): [1] Ha Van Hoang, "Inequality of Household Expenditure on Senior Students' Accessibility to Higher Education in Vietnam," Universal Journal of Educational Research, Vol. 8, No. 12B, pp. 8240-8247, 2020. DOI: 10.13189/ujer.2020.082628.
\end{abstract}

(b): Ha Van Hoang (2020). Inequality of Household Expenditure on Senior Students' Accessibility to Higher Education in Vietnam. Universal Journal of Educational Research, 8(12B), 8240-8247. DOI: 10.13189/ujer.2020.082628.

Copyright $\bigcirc 2020$ by authors, all rights reserved. Authors agree that this article remains permanently open access under the terms of the Creative Commons Attribution License 4.0 International License

\begin{abstract}
The purpose of the research is to study the cost difference in household expenditure on senior students' accessibility to higher education in Danang of Vietnam. This study implements a quantitative research design in a survey method using 788 questionnaires (including 394 12th grade students - seniors at high schools and 394 parents of these students) in Danang of Vietnam. Research results show that, factors such as location, income and education level of parents are correlated with the tuition costs for children accessibility to higher education. There is an inequality of household investment in relation to these factors. In which, families living in the city center with high income and education have higher education spending than those living in suburban and rural areas with income and low education levels, and vice versa. The results of a sociological study show that families with a parent whose average income is from VND 1.1 million to VND 3 million/month (equivalent to USD 55 to USD 150) must spend up to $1 / 2$ of the total monthly income for their Twelfth-grade students. This research can be used for state management agencies, universities, families of student.
\end{abstract}

Keywords Education Spending, Higher Education, High Schools, Student, Social Inequality

\section{Introduction}

Education plays an important role in providing human resources for society as well as contributing to the socio-economic development of nations. Therefore, the fact that a part of the population cannot continue to pursue higher education will make it more difficult to solve the problem of human resource quality [9]. At the same time, higher education is considered as one of the key measures to reduce inequality in the long term [21]. Moreover, higher education is considered as a motivating factor for social mobility if it is open to all students [25]. However, the higher the education, the greater the cost, especially the burden on poor families [46]. Therefore, educational inequality is, therefore, another factor that originates poverty in society [2].

Access to education is understood as the equality of educational opportunities of social groups, different population classes in socio-economic situations, cultural capital, and living location of the family, ethnicity, gender [18] in which, the family's socio-economic situation is considered to be a major influence on the children's education to pursue higher education. The barriers to access to education among low-income students widen the income inequality, which in turn widens the inequality in access to education [45]. At higher levels of education, expenses for greater education, and those with low incomes are often completed education levels are lower in the group with higher incomes. Therefore, income and expenditure factors for education are analyzed as important factors related to inequality in conditions and opportunities for people to access education [10]. For relatively disadvantaged households (household heads with less education, income, or rural hukou status), inequality of opportunity has a larger negative effect on 
their education expenditures [41].

According to the quintile of living standards of the Report on the Results of the Population and Housing Census in 2019 related to the proportion of the population in Vietnam with tertiary education related to the income groups indicated that the percentage of the richest quintile having higher education accounted for $26.2 \%$ compared to $1.3 \%$ seen in the figure for the richest group, a significant gap of $24.9 \%$ between them [6]. Currently, in Vietnam, educational pending for Twelfth-grade students is important in preparing for access to higher education. In Vietnam, households tend to spend a considerable the amount of ron their children's education in the context in which the living standards of Vietnamese families have tended to increase in recent years. Household expenditure on education is a representative indicator of the household's interest in children's education [19]. On average, households spent over 6.6 million VND for a member who is going to school for 12 months, an increase of more than $21.3 \%$ compared to 2016 . In urban areas, households spent 10.8 million VND for a member attending school for 12 months, 2.4 times higher than rural areas; the richest households spent 14.8 million $\mathrm{VND} /$ person/12 months [17]. Therefore, finance becomes one of the factors that create inequality in people's access to education [26]. At the same time, if the number of children of primary, secondary, and high school age increases, the household tends to increase education expenditure, so the education spending in primary, secondary and high children is likely to increase power higher [20].

In general, there have been domestic and foreign studies on social inequality, the influence of factors affecting access to higher education and as well as factors affecting the educational expenditure of households, but there is very little research on the differences and inequality in household educational expenditures for senior high school students, especially in Vietnam, especially in Vietnam. The study shall analyse the differences in education expenditure of households for Twelfth-grade students in Danang of Vietnam.

\section{Literature Review}

Many studies look at the effects of factors on access to education. Regional differences are considered as factors that significantly affected access to education in Greece [51] and in Pakistan [32]. Walsh et al. analyzed the differences and inequalities in access to education among regions of the Republic of Ireland [52]. This is also mentioned in previous studies of Angran, Felicia and Lin also point out the social inequality in access to higher education between urban and rural students [3], [15]. In the study of social inequality and access to higher education in Russia, Konstantinovskiy said that the difference of the type of the secondary school, as well as the effects of living location change in receiving general education, will affect the decision to attend college [23]. Elizabeth, while pointing out barriers to access to higher education in Egypt, also concluded that the ratio of access to higher education for women, young people from rural areas and poor households are lower than the youth groups in the comparison group [14]. Moreover, women's access to education in Asian countries continues to face social and economic barriers [33]. Research by Schuetze and Archer has shown barriers in accessing higher education in Canada including barriers to participation such as cost, affordability, student aid and graduate employment [40]. On the other hand, social identity factors play an important role and influence students' choice and decision to attend university, especially students in difficult circumstances, lower social class [24].

Moreover, the education spending of the household for the children in grade school high school has important implications in continuing higher education. The analysis of Tilak et al. on the factor affecting the ability of Indian farming households to spend on education shows that household income, household size, living position have a positive effect on education expenditure [44]. Tansel shows that the household expenditure and educational level of parents have a great influence on people's education expenditure [43]. Donkol and Amikuzunol, Sarwar et al. concluded that the factors affecting educational expenditures in Ghana include gender, age, education level, valuable assets and location of residence [10], [39].

The results of multivariate regression analysis of factors influencing Chinese household education expenditure from survey data from 2007 to 2011 show that the ability of spending on education depends on income, expenses for tutoring and education of the head of household [53]. The results of the Tobit model analysis show that the factors affecting decisions for the Turkish household's education spending include location of residence, employment, age of household head, education level of the household head, total number of children in a family [13]. The expenditure on children's education significantly increases with the increasing levels of household income. Furthermore, that household head's level of education has an increasingly positive and significant effect on expenditure on children's education, with households in which the heads have received at least college education spending the most on children's education [38], [4], [12].

In Vietnam, research on social inequality and the influence of socio-economic factors on access to education in general and higher education, in particular, has also been paid attention. The results of the 2019 Vietnam Population and Housing Census show that the proportion of the population aged 15 and older with university or higher education in Vietnam by urban living area accounts for $17.7 \%$, while rural areas account for $4.7 \%$ [6]. This means that the chances of getting a university or higher education level in urban residents are 
nearly four times higher than those living in rural areas. Research's Phung shows that urban youth have higher enrolment rates at 1.43 times higher than rural areas [36]. This is also demonstrated in a study on "the relationship between the current situation of education of rural youth and household's choices of access to education" in Vietnam by Tran and Ngo [48]. Analysing children's access to education and the influencing factors, Tran has shown that, although urban areas are considered to have many incentives compared to rural areas, there are also inequalities in access to education in urban areas [47]. The problem of spending on education is also analysed in a study by Duong showing that urban residents often are more likely to pay for education than those in rural areas and therefore have higher access to education [11]. Nguyen and Tran, Pham claims that tuition fees are one of the main barriers to higher education in Vietnam, especially for poor families [27], [34].

Dang also found a significant effect of tutoring costs on household expenditure which is increasing at higher levels [7]. On the basis of the survey data on household living standards, Dao evaluated the impact of household characteristics on secondary education expenditure by using regression analysis [8]. The research results have shown that sex, education of the household head, characteristics of the head of household (location, region, area of residence, economy) affect education expenditure. The analysis results of Tobit's moderated regression model in the study of Khong et al. demonstrated that the key factors influencing people's education expenditure in the Mekong Delta include education level of the head of household, age of household head, total income in a family [22]. Tran and Nguyen were applied the two-stage Heckman model to identify the determinants affecting the decision and amount of investment in the education of the farming households in Tra Vinh province [49]. The estimated results showed that factors affecting the educational investment decision included ethnicity, tuition fees, household poverty status, asset value, and distance to school.

In addition, the assessment of the impact of household characteristics on household education expenditure in Vietnam through regression analysis shows that the ethnicity of the household head, age of the household head, education of the head of the household, and marital status. Head of household, area in which the household lives, total number of people in the household, health expenditure, food expenditure, total expenditure, and region affect household education expenditure. While the household size variable (total number of people in the household) has the opposite effect of household education expenditure, the remaining variables have a positive effect on Vietnamese household education expenditures [35].

\section{Methodology}

This study implements a quantitative research design in addressing the research objectives and was implemented from 2018 to 2019 . The survey subjects were randomly selected with a total stratified sample size of $\mathrm{N}=788$, (394 twelfth grade students, which is the last level in the Vietnamese school, and 394 of their parents (fathers or mothers). These subjects were randomly selected at 7 high schools in 7 districts representing the centre, surrounding, and suburban areas of Da Nang, of which 56 students and 56 parents of students were selected from each of those schools. In fact, the number of men, that is, male students and fathers are less than women at 185 people and 171 people, respectively. In terms of living location, the respondents live in the centre, that is, $29.4 \%$ live in the suburbs and $18.8 \%$ live in rural areas. Among the 394 parents surveyed, there are, $7.4 \%$ having elementary school level, 29.7\% having secondary school level, 33\% having high school level, 3\% having professional secondary level, $4.3 \%$ having college level, $19.5 \%$ having university degree and $3 \%$ postgraduate degree. Regarding the occupation of parents, the largest proportion comprises small traders $(20.6 \%)$. Meanwhile, the figure of state officials, farmers, workers, business, retired people self-employed persons and other group are 70 people, 35 people, 69 people, people, 18 people, 77 people and 6 poeple respectively. Table 1 shows the distribution of participants.

Table 1. Overview of the research sample

\begin{tabular}{|c|c|c|c|c|c|}
\hline \multirow{2}{*}{\multicolumn{2}{|c|}{ Demographic }} & \multicolumn{2}{|c|}{ Parents } & \multicolumn{2}{|c|}{ Students } \\
\hline & & \multirow{2}{*}{$\frac{\mathrm{n}}{171}$} & \multirow{2}{*}{$\begin{array}{c}\% \\
43.4\end{array}$} & \multirow{2}{*}{$\frac{\mathrm{n}}{185}$} & \multirow{2}{*}{$\begin{array}{l}\% \\
47\end{array}$} \\
\hline & Male & & & & \\
\hline 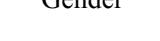 & Female & 223 & 56.6 & 209 & 53 \\
\hline \multirow{3}{*}{ Living Place } & Center & 204 & 51.8 & 204 & 51.8 \\
\hline & Suburban & 116 & 29.4 & 116 & 29.4 \\
\hline & Rural & 74 & 18.8 & 74 & 18.8 \\
\hline \multirow{7}{*}{ Education } & Primary school & 29 & 7.4 & - & - \\
\hline & $\begin{array}{c}\text { Secondary } \\
\text { school }\end{array}$ & 117 & 29.7 & - & - \\
\hline & High school & 130 & 33.0 & - & - \\
\hline & Intermediate & 12 & 3.0 & - & - \\
\hline & College & 17 & 4.3 & - & - \\
\hline & University & 77 & 19.5 & - & - \\
\hline & After university & 12 & 3.0 & - & - \\
\hline \multirow{8}{*}{ Occupation } & Public servants & 70 & 17.8 & - & - \\
\hline & Farmer & 35 & 8.9 & - & - \\
\hline & Worker & 69 & 17.5 & - & - \\
\hline & Small business & 81 & 20.6 & - & - \\
\hline & Business & 38 & 9.6 & - & - \\
\hline & Retire & 18 & 4.6 & - & - \\
\hline & Self-employed & 77 & 19.5 & - & - \\
\hline & Other & 6 & 1.5 & - & - \\
\hline
\end{tabular}


At the same time, the study used mathematical-statistical methods through software SPSS, Version 22. The statistics used include: mean score, standard deviation, correlation to consider the relationship between factors and the education spending; One-Way ANOVA (One-Way ANOVA) analysis analyzes differences in the education spending of households with different socio-economic characteristics.

\section{Result and Discussion}

Education investment for children is very important, especially the senior grade - grade 12 (the end of high school in Vietnam). Usually, the more attention the family and the community have, the more attention they have given to educational support and the higher the educational level of the people. One of the important indicators that reflect parents' interest in their children's education is education spending. There are many factors related to the tuition costs of households to their children (Table 2).

The analysis of the correlation between the monthly tuition costs and the factors from Table 2 proves that the educational investment for children has a relation to the living location ( $\mathrm{r}=-0.195)$, the average monthly income of one parent $(\mathrm{r}=0.323)$ and the education level of one parent $(\mathrm{r}=0.262)$. In particular, the tuition cost is positively correlated with the average monthly income and educational level of the parent. That is, the higher the income, the higher the education level, the greater the investment in children's education.

Significant differences in the tuition costs between different locations of the household (Table 3) exist.

The research results from Table 3 show that the average monthly spending for grade 12 students in Danang city is quite high, at VND 1.98 million (approximately USD 99). These costs are higher than one third $(36 \%)$ of the average monthly educational spending for a member attending school (including all education levels) of Vietnamese households (VND 5.5 million, equivalent to USD 275) in 2016 [16]. However, the average monthly education spending for a household member in Da Nang is 0.83 times lower than that of Hanoi households (VND 2.37 million/child/month or USD 120) and less than VND 1.42 million (approximately USD 71) compared to the spending of households in Ho Chi Minh City (VND 3.4 million /child/month (equivalent to USD 170) in 2016 [29].

Table 2. Correlation between school fees and factors

\begin{tabular}{|c|c|c|c|c|c|c|}
\hline Factors & 1 & 2 & 3 & 4 & 5 & 6 \\
\hline 1. Monthly tuition cost & 1 & & & & & \\
\hline 2. Living location & $-0.95^{* *}$ & 1 & & & & \\
\hline 3. Moving status & 0.034 & -0.048 & 1 & & & \\
\hline 4. Occupation & -0.050 & -0.085 & -0.020 & 1 & & \\
\hline 5. Average Monthly Income & $0.323^{* *}$ & $-0.189 * *$ & 0.096 & -0.068 & 1 & \\
\hline 6. Education level & $0.262^{* *}$ & $-0.242 * *$ & 0.097 & $-0.277 * *$ & $0.384 * *$ & 1 \\
\hline
\end{tabular}

$* * \mathrm{p}<0.01$

Table 3. Differences in tuition costs in relation to living location

\begin{tabular}{|c|c|c|c|}
\hline Living location & $\begin{array}{c}\text { Mean } \\
\text { (M) }\end{array}$ & $\begin{array}{c}\text { Standard deviation } \\
\text { (SD) }\end{array}$ & F \\
\hline City centre & 2.12 & 0.77 & \\
\cline { 1 - 3 } Centre surrounding area & 1.90 & 0.70 & \multirow{2}{*}{$0.00^{*}$} \\
\hline Suburban area & 1.74 & 0.74 & \\
\hline
\end{tabular}


The research data from Table 2 also shows that there is a statistically significant difference $(\mathrm{F}=7.39, \mathrm{p}=0.00)$ in the average monthly tuition costs for grade 12 students among families living in Geographical region of Danang city. Among them, the households in the centre area have the highest monthly average of VND 2.12 million (equivalent to USD 100), followed by those in the surrounding areas (VND 1.9 million), equivalent to USD 96) and the end of suburban households (VND 1.74 million, equivalent to USD 87). Thus, the households investment in education for children in general as well as for high school seniors in the centre region is higher than that in the surrounding and suburban - rural areas. At the same time, Post hoc comparisons using the Tukey HSD test indicated that difference in monthly tuition costs between households living in the city centre with surrounding areas $(\mathrm{M}=2.12, \mathrm{SD}=0.77)$ and suburban areas $(\mathrm{M}=1.74, \mathrm{SD}=0.74)$. In particular, households in the centre area spend more monthly on their children's education than surrounding areas than those in suburban areas. On the other hand, the research results also show that there is no significant difference in the level of education spending for children between households living in surrounding and suburban areas. Research results by Trinh, Nguyen and Bui also showed that urban spending on education is much higher than in rural areas, especially wealthy households [50], [28], [5]. Thus, although there is a difference in the tuition cost for grade 12 students of the household across regions of Danang, the gap is not too large compared to the average monthly education spending for one member attending school (including all education levels) of a household between urban and rural areas of Vietnam in 2016 (urban household (VND 9.1 million, equivalent to USD 455) costs are 2.4 times higher than that of rural households) [16].

In addition to the disparity in the tuition costs between different living locations of households, there is a significant difference between the tuition costs for children in relation to the average monthly income of the parents (Table 4).

Table 4. Differences in tuition costs in relation to income

\begin{tabular}{|c|c|c|c|c|}
\hline Income (VND) & $\begin{array}{c}\text { Mean } \\
(\mathrm{M})\end{array}$ & $\begin{array}{c}\text { Standard } \\
\text { deviation } \\
\text { (SD) } \\
\end{array}$ & $\mathbf{F}$ & $\mathbf{p}$ \\
\hline Less than 1 million & 1.33 & 0.61 & \multirow{5}{*}{11.82} & \multirow{5}{*}{$0.00^{*}$} \\
\hline $\begin{array}{c}\text { From } 1.1 \text { to } 3 \\
\text { million }\end{array}$ & 1.64 & 0.65 & & \\
\hline $\begin{array}{l}\text { From } 3.1 \text { to } 5 \\
\text { million }\end{array}$ & 1.97 & 0.69 & & \\
\hline $\begin{array}{c}\text { From } 5.1 \text { to } 10 \\
\text { million }\end{array}$ & 2.11 & 0.68 & & \\
\hline Over 10 million & 2.33 & 0.94 & & \\
\hline
\end{tabular}

$* \mathrm{p}<0.05$
Research results from Table 4 indicate that the higher the income households have, the higher the investment in education for children attending last year of high school, particularly families with a parent whose income is over VND 10 million/month (equivalent to more than USD 500) spent on children's education at 2.33 million $\mathrm{VND} /$ month (equivalent to USD 100), accounting for $1 / 5$ of the parents' total income. A family with a parent earning from VND 5.1 million to VND 10 million /month (equivalent to USD 250 to USD 500) invest in education for children at 2.11 million VND (equivalent to USD90). These expenses are appropriate with the income and are affordable. However, it becomes a burden for families whose parents have a low income of less than VND 1 million/month (equivalent to less than USD 50) to spend VND 1.33 million for the education of children or families with a parent whose average income is from VND 1.1 million to VND 3 million/month (equivalent to USD 55 to USD 150) must spend up to $1 / 2$ of the total monthly income for their children's education at the senior level.

On the other hand, the research data from Table 4 also clearly demonstrated that there is a statistically significant difference $(\mathrm{F}=11.82, \mathrm{p}=0.00)$ in monthly investment spending among household income groups. Lowest income Household Group (less than VND 1 million, equivalent to USD 50) with tuition speeding is lower than the remaining income groups. At the same time, the highest income group of over VND 10 million/month (equivalent to more than USD 500) has a higher speeding than other groups, especially this income group $(\mathrm{M}=2.33$, $\mathrm{SD}=0.94$ ) has cost nearly 2 times higher than the speeding of the lowest income households $(\mathrm{M}=1.33, \mathrm{SD}=0.61)$. In addition, there is no statistically significant difference between the lowest income group (less than VND 1 million, equivalent to USD 50) and the middle-income group (from VND 1.1 million to VND 3 million/month, equivalent to USD 55 to USD 150) or middle-income group from 3.1 million dong VND to 5 million VND / month and income groups of VND 5.1 million to VND 10 million/month in monthly tuition spending for their children. This means that these households have similar tuition spending for their children. Thus, the higher the income families, the greater the spending, the more attention are focused on the children education. This further expands and enhances higher education access opportunity for their children. Similar results are also found in previous studies [42], [7], [37], [47].

Not only does the disparity in the level of education investment for children among households with different levels of income and living position differ but the tuition costs are also reflected in relation to the education level of a parent (Table 5). 
Table 5. Differences in tuition costs in relation to education level

\begin{tabular}{|c|c|c|c|c|}
\hline Education level & $\begin{array}{c}\text { Mean } \\
\text { (M) }\end{array}$ & $\begin{array}{c}\text { Standard } \\
\text { deviation } \\
\text { (SD) }\end{array}$ & F & p \\
\hline Primary school & 1,55 & 0.63 & & \\
\cline { 1 - 3 } Middle school & 1,84 & 0.74 & & \\
\cline { 1 - 3 } High school & 1,97 & 0.70 & \multirow{2}{*}{5.3} & \multirow{2}{*}{$0.00^{*}$} \\
\cline { 1 - 3 } Intermediate & 2,25 & 1.06 & \\
\cline { 1 - 3 } College & 2,06 & 0.75 & & \\
\cline { 1 - 3 } University & 2,25 & 0.76 & & \\
\hline Postgraduate & 2,50 & 0.90 & & \\
\hline
\end{tabular}

$* \mathrm{p}<0.05$

Through ANOVA's in-depth analysis, the research data in table 5 show the differences in the tuition costs for the children of the households in relation to the education level of parents $(\mathrm{F}=5.31, \mathrm{p}=0.00)$. Families with one parent with primary education were the lowest of VND 1.55 million/month (approximately USD 80), and households with father/mother who had the upper level (Primary, junior high and high school) invested in learning for children less than VND 2 million/month (equivalent to less than USD 100). However, families with a parent with professional education (from Intermediate, College, University and Postgraduate) spent more than VND 2 million a month (equivalent to more than USD 100) for children; especially families with father/mother having Postgraduate level spent the highest of VN 2.50 million/month (approximately USD 125).

The research results also show that there is a statistically significant difference in terms of the tuition cost between different education levels of parents. In particular, for families with parents with primary school ( $M=1,55, \mathrm{SD}=0,63)$, the spending is lower than families with parents with remaining groups, except in comparison with families with parents of junior high school level. On the one hand, the group of families with a parent with a postgraduate education level $(\mathrm{M}=2,50, \mathrm{SD}=0,90)$ has higher spending than a family with a high school education (primary, Middle school, high school), especially a quarter higher than the families with a parent with primary education. However, the group of families with parents with Postgraduate level does not have a statistically significant difference compared to families with parents with the professional education level of Intermediate, College, University). Thus, families with parents with higher levels of education, the greater the investment cost for children. This issue once again emphasizes the relationship between education level and income as well as costs, especially the tuition costs. At the same time, this issue also confirms the reproduction of inequality in education as well as the opportunity to access higher education. This is also consistent with the results of previous studies. Households with tertiary education have an increased likelihood of spending on education [30], [1]. The households headed qualifications graduated high school spending higher than households headed lower secondary qualifications [31].

\section{Conclusions}

Household investment in education is one of the factors that is closely related to students' access to higher education. In addition to ability and institutional factors, the tuition cost has become a barrier to access to higher education for households.

Investments in education for high school seniors to enhance the access to higher education of households are strongly correlated with factors such as location, income and parent's education level. At the same time, there are differences and disparities in the tuition costs for children between households in the city centre and households living in surrounding, rural and suburban areas; between high and low-income family groups; between households with a parent with low education level. Thus, once again asserting that the educational investment of households contributes to limiting barriers and increasing their children's access to higher education.

\section{Recommendations}

In order to minimize social inequality in household expenditure for accessibility to higher education in Vietnam, it is necessary to synchronously apply the following solutions:

Strictly comply with the Instruction of the Ministry of Education and Training of Vietnam on tutoring in order to limit the tutoring and increase learning in official schools.

Expand access to high-quality general education for students from income families and rural communities.

The Government needs to expand the borrowers of loans not only for students but also students in high school, especially students from low-income households.

Continue to improve the training quality of universities in specialized fields associated with the needs of each locality, in order to reduce learning costs for students in rural areas when attending university.

\section{Limitation and Suggestions for Further Study}

This study analyzed the inequality in household education expenditures for Twelfth-grade students only in Danang, Vietnam. The comparison of inequality in education spending by households for students end high school level between the regions of Vietnam in particular and between Vietnam and other countries in the world, especially with the ASEAN countries is essential. 


\section{REFERENCES}

[1] Acerenza S., N., Gandelman, "Household Education Spending in Latin America and the Caribbean: Evidence from Income and Expenditure Surveys", Education Finance and Policy, vol. 14, pp. 61-87, 2019. DOI: 10.1162/edfp_a_00241

[2] Alberto I. P. R., R. F. Jesús, E. N. R. Ana, "Educational Inequality in Nuevo Leon and Oaxaca, Mexico, 2008 and 2010: The Basis of an Uncertain Future for These Societies", Universal Journal of Educational Research, vol. 5, no. 7, pp. 1233-1240, 2017. DOI: 10.13189/ujer.2017.050715.

[3] Angran L., "Unfulfilled promise of educational meritocracy? academic ability and China's urban-rural gap in access to higher education". Journal Chinese Sociological Review, vol. 51, no. 2, pp, 115-146, 2019. DOI: $10.1080 / 21620555.2019 .1579052$

[4] Bayar A. A., I. B. Yanik, "Determinants of Household Education Expenditures: Do Poor Spend Less on Education?", Topics in Middle Eastern and African Economies, vol. 18, no. 1, pp. 83-111, 2016.

[5] Bui T. H. A., Analyzing consumer spending of households between urban and rural areas in Can Tho city, University of Economics Ho Chi Minh City, Vietnam, 2019.

[6] Central Census Steering Committee, Results of the census of population and housing at $0 o^{\prime}$ clock april 1, 2019. Statistical publishing house, Vietnam, 2019.

[7] Dang H. A., "The determinants and impact of private tutoring classes in Vietnam", Economics of Education Review, vol. 26, no. 6, pp. 683-698, 2007.

[8] Dao T. Y. N., Evaluate the impact of household characteristics on secondary education expenditure of on Vietnamese household, University of Economics Ho Chi Minh City, Vietnam, 2013.

[9] Do T. K., "Gender inequality in education in Vietnam today", Jouarnal of Sociolology, vol. 1, no. 109, pp. 49-56, 2010.

[10] Donkol S. A., J. A. Amikuzunol, "Factors influencing education expenditure in Ghana", Educational Research Reviews, vol. 6, pp. 40-52, 2007.

[11] Duong C. T., "Inequality between urban and rural areas in access to education in Vietnam". Vietnam Social Sciences, vol. 3, no. 76, pp. 73-84, 2014.

[12] Ebaidalla M. E., "Understanding Household Education Expenditure in Sudan: Do Poor and Rural Households Spend Less on Education?", African Journal of Economic Review, vol. 6, no. 1, pp. 160-178, 2018. DOI: 10.22004/ag.econ.274749

[13] Elif O. A., "An empirical analysis of household education expenditures in Turkey", International Journal of Educational Development, no. 51, pp. 23-35, 2016. DOI: 0.1016/j.chieco.2015.11.008

[14] Elizabeth B., "Access to higher education in Egypt: examining trends by university sector", The University of Chicago Press Journal, vol. 57, pp. 527-552, 2013. DOI:

\section{$10.1086 / 670665$}

[15] Felicia F. T., C. Lin, "Rural - urban inequality in Chinese higher education" in Higher education and career prospects in China, Felicia F. T., Lin Ch., (eds.), Palgrave Macmillan, 2019.

[16] General Statistics Office, Results of the Vietnam living standards survey 2016, Statistical Publishing House, Vietnam, 2016

[17] General Statistics Office, Results of the Vietnam living standards survey 2018, Statistical Publishing House, Vietnam, 2019.

[18] Ha V. H., V. V. Fursova, Accessibility of higher education in Russian and Vietnamese societies: A comparative analysis, Kazan University Press, Russia, 2019.

[19] Hoang T. N, "The model analyse the factors affecting Vietnamese household expenditure on education, Journal of International Economics and Management, 2020. URL: http://tapchi.ftu.edu.vn/các-số-tạp-ch\%C3\%AD-ktđn/176-ta p-ch\%C3\%AD-ktđn-số-110-đến-số-119/tạp-ch\%C3\%AD-k tđn-số-112.html (accessed on 18 July 2020).

[20] Huy V. Q., "Determinants of educational expenditure in Vietnam", International Journal of Applied Economics, vol. 9, no. 1, pp. 59-72, 2012.

[21] Johansson J., Income inequality and higher education: a review of the empirical evidence. Höstterminen, 2019. URL: http://www.diva-portal.org/smash/get/diva2:1415604/FUL LTEXT01.pdf (accessed on 29 July 2020).

[22] Khong T. D., L. T. Pham, "Factors influencing on education spending of people in the Mekong Delta". Can Tho University Journal of Science, vol. 31, pp. 81-90, 2014.

[23] Konstantinovskiy D. L., "Social inequality and access to higher education in Russia", European Journal of Education, vol. 1 , no. 47 , pp. 9-24, 2012. DOI: $10.1111 /$ j.1465-3435.20 11.01504.x

[24] Marlon N., Antony S. R. M., J. E. Matthew, “Accounting for unequal access to higher education: the role of social identity factors", Group Processes and Intergroup Relations, vol. 22. no 3, pp. 371-389, 2019. DOI: 10.1177/1368430219829824

[25] Melanie W., The achievement of university access: conversion factors, capabilities and choices", Social Inclusion, vol. 7, no. 1, pp. 52-60., 2019. DOI: 10.17645/si.v7i1.1615

[26] Nguyen D. T., "Several factors influence the poor's access to education and health from a human development perspective", Journal of Human Research, vol. 6, pp. 25-38, 2010.

[27] Nguyen D. T., T. T. H. Tran, The trend of educational change of rural households in the Doi Moi period", Journal of Sociology, vol. 2, no. 126, pp. 37-48, 2014.

[28] Nguyen M. T., Evaluation of factors affecting educational expenditure of Vietnamese rural - urban households. University of Economics Ho Chi Minh City, Vietnam, 2014.

[29] Nguyen T. L. H., "Expenditure on education among households in Vietnam in 2015", 2016. URL: http://ncif.gov.vn/Pages/NewsDetail.aspx?newid=18779, (accessed 15 July 2020). 
[30] Nguyen T. X. T., The impact of household characteristics to education spending in Vietnam, University of Economics Ho Chi Minh City, Vietnam, 2018.

[31] Nguyen T. V., Basic factors affecting educational expenditure of households in Ho Chi Minh City, University of Economics Ho Chi Minh City, Vietnam, 2019.

[32] Noor F., I. A. Muhammad, Z. Sania, "Higher Education Policy \& Research in Pakistan: Challenges in Transformation of the Society and the Way Forward", Universal Journal of Educational Research, vol. 8, no. 7, pp. 2842-2852, 2020, DOI: 10.13189/ujer.2020.080711.

[33] Olson-Strom S., N. Rao, "Higher education for women in Asia", in Diversity and inclusion in global higher education (Catherine S. S., W. G. Nancy, (eds.), Palgrave Macmillan, 2020.

[34] Pham T. L., "Tuition and accessibility to higher education", VNU Newsletter, vol. 294, pp. 42-47, 2015.

[35] Phan K. L., The assessment of the impact of household characteristics on household education expenditure in Vietnam, University of Economics Ho Chi Minh City, Vietnam, 2017.

[36] Phung T. K. A., "The influence of the family on the higher education of young people in Hanoi", Journal of Family and Gender Studies, vol. 5, pp. 39-51, 2010.

[37] Reham R., O. A. John, "Determinants of household expenditure on children's education in Egypt", International Journal of Education Economics and Development, vol. 5, no. 4, pp. 332-360, 2014.

[38] Rizk R., J. Owusu-Afriyie, "Determinants of household expenditure on children's education in Egypt", Journal of Education Economics and Development, vol. 5, no. 4, pp. 332 - 360, 2014. DOI: 10.1504/IJEED.2014.067194

[39] Sarwar G., Sial M. H., M. S. Muhammad, "Determinants of Household Investment in Education in Pakistan", Journal of Education \& Social Sciences, vol. 7, no. 2, pp. 67-78, 2019. DOI: $0.20547 /$ jess0721907205

[40] Schuetze H. G., W. Archer, "Access to and participation in higher education in Canada" in Preparing Students for Life and Work - Policies and reforms affecting higher education's principal mission, (Schuetze H. G., W. Archer, (eds.), Leiden and Boston: Brill-Sense, 2019.

[41] Song, Y., G. Zhou, "Inequality of opportunity and household education expenditures: Evidence from panel data in China", China Economic Review, vol. 55, no. C, pp. 85-98, 2019. DOI: 10.1016/j.chieco.
[42] Sulaiman N., Ismail R., Othman N., B. T. Poo, "The determinants of demand for Education among households in Malaysia", International Business Management, vol. 6, no. 5, pp. 558-567, 2012. DOI: 10.3923/ibm.2012.558.567

[43] Tansel A., "Demand for education in Turkey: A tobit analysis of private tutoring expenditures", Economics of Education Review, vol. 13, no. 4, pp. 303-313, 2005. DOI: 10.1016/j.econedurev.2005.02.003

[44] Tilak J. B. G., Determinants of household expenditure on education in rural India, National Council of Applied Economic Research., 2002.

[45] Tilak J. B. G., P. K. Choudhury, Inequality in access to higher education in India between the poor and the rich: An Analysis of $64^{\text {th }}$ and $71^{\text {st }}$ Rounds of NSSO Data (2007-08 and 2013-14), Council for social development, 2019.

[46] Tran H. Q., From parents to teachers: Socio-economic problems in general education, Culture Publishing House, Vietnam, 2018.

[47] Tran Q. L., "Access to education for Vietnamese children and its influences", Journal of Human Studies, vol. 4, pp. 48-58, 2014

[48] Tran T. T. H., T. T. T. Ngo, "The relationship between the educational situation of rural youth and the household's access to education". VNU Journal of Science, vol. 3, no. 30, pp. 22-30, 2014

[49] Tran T. C., V. V. A. Nguyen, "Determinants affecting households' expenditure on education in Travinh province" The Scientific Journal of Tra Vinh University, vol. 1, no. 28, pp. 1-10., 2017. https://doi.org/10.35382/18594816.1.28.20 17.38 .

[50] Trinh T. A. H., V. C. Nguyen, "The poor's access to education in the context of educational socialization", Journal of Educational Management, vol. 55, pp. 1-4, 2013.

[51] Verdis A., Kalogeropoulos K., C. Chalkias, "Regional disparities in access to higher education in Greece", Research in Comparative and International Education, vol. 2, pp. 318-335, 2019. DOI: 10.1177/1745499919846186

[52] Walsh S., Flannery D., J. Cullina, Geographic accessibility to higher education on the Island of Ireland. Irish Educational Studies, vol. 34, no. 1, pp. 1-19, 2015. DOI: $10.1080 / 03323315.2015 .1010302$

[53] Wei C., X. Qian, "Human capital investment in children: An empirical study of household child education expenditure in China, 2007 and 2011", China Economic Review, vol. 37, no. C, pp. 52-65, 2015. DOI: 10.1016/j.chieco.2015.11.008 